\title{
What's in a name?
}

\section{Linnaeus' marginal jottings created order out of botanical chaos.}

\section{Sandra Knapp}

L amenting her love for the 'wrong' man, Juliet muses, "What's in a name? that which we call a rose By any other name would smell as sweet". She asserts that Romeo's 'essence', his goodness, desirability and character, transcends his name. An Elizabethan botanist in the audience at the Globe theatre might have agreed, not because he (and he surely would have been a man) believed names were of no consequence, but because he too would have relied on defining the essence of things.

Humans have invented many different systems of naming. Throughout the Dark Ages in Europe, monks copied and re-copied the treatises of the Greek natural philosophers, keeping their naming systems alive. Aristotelian logic, a force in the natural sciences until the mid-nineteenth century, required that names reflect hidden reality or essence. A name thus consisted of a generic part (character naturalis), the essence of the organism, and a specific part (differentia), distinguishing it from all others in the genus. Names were usually Latin phrases, polynomials, but could be a single word. Consistency was not the order of the day.

Revolution arrived in the eighteenth century in the shape of Carl Linnaeus, who has been called many things - the first ecologist, a botanical pornographer and a "compleat naturalist". It was said, "God created; Linnaeus arranged", and the man himself was certainly not reticent about his own abilities. The task he undertook was to catalogue all life. Being a medical doctor and a botanist, he naturally concentrated on plants.

As Europeans began to explore the rest of the world, they brought back organisms from far-away lands - especially plants, which could be grown easily in the gardens and hothouses of rich patrons of science. The sheer diversity may not be so remarkable to us today - Linnaeus' catalogue of the world's flora comes to only about 9,000 taxa - but it severely strained the polynomial system of naming. To differentiate one or two similar things is easy, but when the numbers increase, names become cumbersome and impossible to memorize.

Linnaeus, for whom brevity was an ideal - "for beauty and perfection science requires conciseness and brevity" — invented a system of nomina trivialia, trivial names, to run in parallel with the phrase-names required by Aristotelian logic. His greatest botanical work, Species Plantarum, was published in 1753, after 20 years of labour. It was

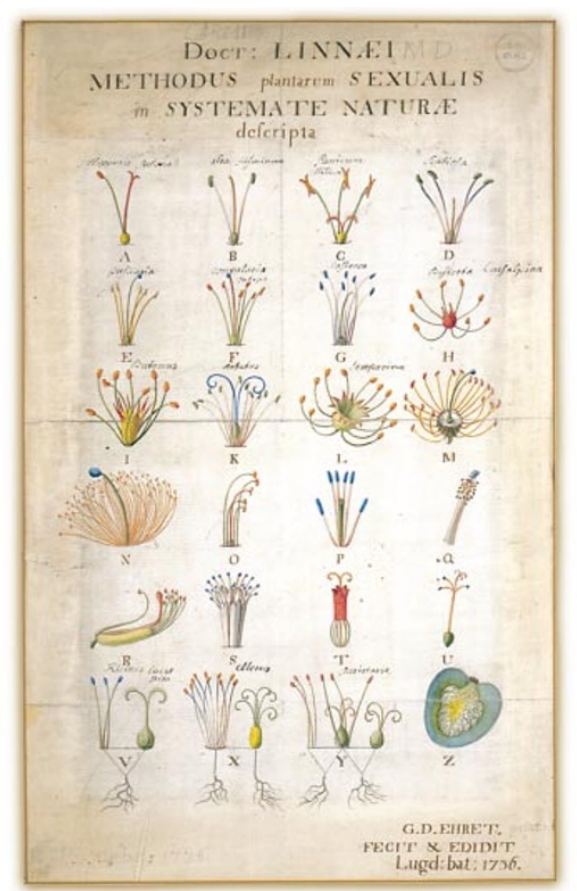

Botanical pornography? Georg Ehret's drawing of the Linnaean 'sexual system' of plants.

a complete catalogue of all known plants but in it Linnaeus used for the first time his trivial names as marginal notes - not to replace 'proper' names, but as a way of allowing botanists to mentally organize the everincreasing diversity. Thus, the tomato had a botanical name of "SOLANUM caule inerme herbaceo, foliis pinnatis incisis, racemis simplicibus" (SOLANUM with a smooth herbaceous stem, incised pinnate leaves and a simple inflorescence), which was equated with earlier botanists' names - Bauhin's 1620 "Solanum pomiferum, fructu rotundo striato molli" (apple-like solanum with a round, smooth, striped fruit) and Mattioli's 1586 "Poma amoris" (apple of love). For convenience, in the margin of the text, Linnaeus gave the tomato, in the genus SOLANUM, the trivial name of "lycopersicum". Despite an initially cold reception from the learned, the simplicity of Linnaeus' system recom-

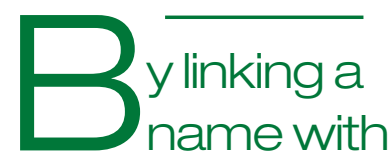

a single specimen, biology becomes a repeatable science. mended it to botanists and gardeners alike, and by the time he died in 1778 binary nomenclature was firmly established.

Nomenclature is often dismissed as the arcane, sterile province of academic taxonomists. But without a name, we find it impossible to communicate about even common objects - witness the confusion caused by an English child asking for a rubber in a US classroom. Biological nomenclature as we know it today began with Linnaeus. Our ability to call a rose, not by any name, but by a precise name such as Rosa canina or Rosa multiflora, allows us to communicate in a common language. By referring to specimens or drawings, Linnaeus tried to link the name with a real object. The type method, devised as a way to control the application of names in the early part of the twentieth century, further refined this link. By linking a name with a single specimen, which can be examined again and again, biology becomes a repeatable science. Scientific names, the genus and species, provide reference points in biological space to which we may compare future discoveries and information.

But although names imply an underlying order, it is folly to equate them with 'biological reality'. Our concept of how organisms are related differs radically from that of Linnaeus or that of Charles Darwin, and is improving all the time. Concepts of what a species actually is are also changing as knowledge increases - not only knowledge as to the extent of diversity, but also that of the genetic structure inherent in all living things. So names change, but rather than being irritated that the tomato is now known as Solanum lycopersicum rather than Lycopersicon esculentum (interesting that Linnaeus got it right, at least according to today's experts), we should reflect on the fact that an advance in knowledge underpins the change. Nomenclature comprises more than just species and genus names, however, and debate rages as to how biologists should reflect hierarchy and classification in their naming systems.

By inventing a simple, concise method of naming organisms by genus and species, Linnaeus revolutionized biology. How much more useful to know that the creature from whom we obtain DNA sequence is Drosophila melanogaster - comparable to other such flies, its identity verifiable and our results repeatable - rather than one of Jorge Luis Borges's creatures "that from a long way off look like flies".

Sandra Knapp is in the Department of Botany, Natural History Museum, Cromwell Road, London SW7 5BD, UK. 